\title{
Strategy Based Making Instruction Management Information Framework (EMIS)
}

Ayumi Aya', Chieko Emi ${ }^{2}$

Universitas

Kochi Japan

e-mail: ayumi.aya25@yahoo.com , c. hieko.emi@yahoo.com ,

To cite this document:

Aya, A., \& Emi, C. . (2020). Strategy Based Making Instruction Management Information

Framework (EMIS). IAIC Transactions on Sustainable Digital Innovation (ITSDI), 2(1), 85-93.

DOI : https://doi.org/10.34306/itsdi.v2i1.357

\begin{abstract}
The Education Management Information System (EMIS) is planned for share genuine data like allies of strategy creators. This examination intends to depict and investigate the execution of EMIS in strategy making in the Mapenda zone of the Ministry of Religious Affairs region Gunungkidul. The exploration results show that EMIS is compared to a base learning data for strategy making can't yet be utilized viably ideal. EMIS data is utilized distinctly as right on time as essential data cross-check through face to face gatherings or by means of phone correspondence so it requires some investment. The obstruction was that the EMIS information assortment measure was attempted distinctly at specific occasions so the data was not refreshed consequently, EMIS application issues, EMIS the executives skill, and the cooperation of madrasah chiefs in information assortment.
\end{abstract}

Keywords: EMIS, Policy Making

\section{Introduction}


There have been numerous improvements in innovation, data and correspondence (ICT) change the viewpoint (mentality), and the executives rehearse in all fields, including instruction. This ICT has prompted an upset in "customary" instruction "current" training both in the learning cycle (learning cycle) and the board (the executives). Regarding training the board, use Information innovation based administration is significant so as to be an arrangement that can be taken by need dependent on exact information and precise. The appropriateness among necessities and approaches gave by the board will carry training to the accomplishment of the objectives set.

Innovation and data as information assortment bases have a job significant in supporting the accomplishment of instructive objectives. As is in the body's metabolic framework, information and data resemble blood because an individual can endure and do day by day exercises. On the off chance that an instructive foundation doesn't get information and backing quality data, it will positively encounter hindrances and troubles, the more so in the vital dynamic cycle. This circumstance resulted in the disappointment of instructive objectives Therefore, organizations training must have a decent, exact and precise information assortment framework give great quality assistance and as a reason for dynamic.

Directorate of Madrasah and Religious Education (Mapenda), as one an office under the Ministry of Religion which is answerable for usage of strict instruction 2 - Madrasah and school - in their information has utilized a training the executives data framework known as EMIS (Education Management Information System). EMIS utilized inside the Ministry of Religion contains the data required in instructive dynamics. This framework records about the number foundations, instructors and showing staff, claimed offices, and others. With this framework, it is trusted that the approaching information will be more precise and nonstop can be refreshed persistently (update) so it tends to be utilized as a premise end of strategy.

Preferably, strategy making requires a substantial information source and simple to peruse. Substantial and simple to peruse information is required as contemplations utilized in any arrangement settling on or time-bound dynamic. Thus the part of information in strategy making is significant. On the off chance that an arrangement is planned without depending on information it is sure that the approach won't be ready to be a difficult solver, however it turns into another issue. Mapenda as a segment in the hierarchical structure of the Ministry of Religion of Gunungkidul Regency answerable for the running of instruction in madrasah and schools ought to have the option to make strategy utilizing the framework the board data (EMIS) held. Notwithstanding, when it will choose an approach, Mapenda Gunungkidul Regency actually requests information got back from madrasah and strict instruction instructors. This shouldn't be this needs to occur if Mapenda is the agent and leader of instruction approaches Islam oversees and upgrades the utilization of EMIS in recovery Policy.

This investigation looks to examine the execution of instruction by the executives Information System (EMIS) in Policy Making in the Mapenda Environment Ministry of Religion of Gunung Kidul Regency. The difficult you need to answer is what is the progression of strategy making, the foundation in utilizing Education Management Information System (EMIS) on strategy making, and usage of the Education Management Information System (EMIS) in recovery strategy in the Mapenda of the Ministry of Religion, Gunungkidul Regency.

\section{Management information System}


The idea of Management Information Systems in associations as of now exists before PCs were developed. Traditional administration data frameworks is a foundational employment, for example, plan recording, filing, correspondence among authoritative chiefs, introducing data for recovery choice, 3 however with the accessibility of information preparing innovation with PCs generally modest, presently and later on to utilize PCs supporting the administration data framework is inescapable. Data which is prepared utilizing a decent data framework can be utilized by the authority of the association or people with the skill had as correspondence implies taking care of issues and data that is truly important in dynamic.

There are a few sentiments with respect to the meaning of the executives data frameworks. Of these few suppositions essentially share for all intents and purpose. Here are a couple of meaning of the board data frameworks. 4 Suyadi Prawirosentono deciphered this administration data framework as a foundation that encourages parties the board that requires data for hierarchical dynamic based on Total Quality Management with the point of winning the opposition through the assembling of items as per the nature of customers. Vincent as cited by the administration data framework is an organization of methods information preparing created inside an association and set up when regarded important with the goal of giving information to every administration time is required, both inward and outside information the premise of dynamic as far as authoritative goals. Walter $\mathrm{J}$ Kennevan, The administration data framework is a composed method of giving past data, present data, and data extended on identified with interior and outer tasks.

Different meanings of the administration data framework on the fact of the matter is a PC based framework used to give different data as information that can be utilized as a premise authoritative choice making.An data framework is worked with a few phases of advancement just as including assets from a few distinct controls, the two sides the board, data innovation, account, etc. One of the outcomes of the data framework improvement item is an incorporated programming, combined with the standards that are applied to deal with the framework so the goals of a framework can be accomplished.

Advancement of a data framework both for an enormous scope and little, however requires organized and composed advances since data framework improvement is an improvement venture has a reason with the goal that the data framework can run well data has 5 fundamental segments, specifically 6 gadget parts (equipment), programming segments (programming), asset segments human (brainware), PC network segments (organization), and segments information asset (data set).

So as to assemble solid data, a framework is required Management Information (SIM) which can oblige and handle information and produce exact and precise data without fail. Without help A solid SIM, it will be hard for a decent association to be acknowledged, in light of the fact that SIM helps organizations of any sort in coordinating information, quicken and arrange information handling, improve quality data, empowering the formation of new administrations, expanding control, robotizes a portion of the normal work, disentangles the enrollment stream or budgetary cycles, etc. Despite the fact that Information Technology (IT) has grown quickly too permits understanding the fantasies of an association, particularly in the field instruction, however it is difficult to construct or utilize a SIM, or in the realm of training known as e-Education.

\section{Education Management Information System (EMIS)}


EMIS (Education Management Information System) is a strategy formal administration in giving exact and exact instructive data time so the cycle of dynamic, arranging, improvement ventures, and other instructive administration capacities can be actualized successfully. In another sense EMIS is a gathering of data and composed documentation in doing the assortment, stockpiling, handling, examination, and scattering of data utilized for the board and instructive arranging. EMIS frameworks are utilized to arrange information and a lot of instructive data that can be perused, recovered, prepared, investigated, and introduced and dispersed.

The quintessence of this definition is an administration data framework training that composes instructive information and data to be put away, oversaw, examined, and utilized in instructive dynamics. Utilization of EMIS in training the executives data frameworks in climate of the Ministry of Religion has the accompanying goals. 8 (1) Strengthen the capacity to compose, plan, and screen the progression of data between related organizations. (2) Integrating all data identified with the administration of instructive exercises and presenting them succinctly and exhaustive. (3) Improve handling limit, stockpiling, and information investigation to give solid and opportune data to organizers, pioneers, and individuals responsible for instruction. (4) Coordinate the cycle of assortment, stockpiling, handling, investigation and spread of data in instruction of the executives. (5) Facilitate and expand the utilization of fitting data by different organizations and people at all levels so that arranging, execution, and the board instruction can be more successful. (6) Simplify profound data stream dynamic by disposing of duplication and errors filling in data. (7) Linking different existing data frameworks. (8)Combining different wellsprings of quantitative and subjective data in a frameworks, and (9) Improve the assortment, dispersal and use measures data the executives instruction because of changing needs data.

\section{Policy Making}

As a rule, the term strategy is characterized as a choice taken by the administration which affects society, so arrangements are frequently alluded to as open strategies, which in their turn of events, the area of strategy examined is progressively expansive. Previously, public approach was distinctly about arrangements in the fields of safeguard, law, and unfamiliar relations, will however today the issue of strategy additionally reaches out to the field of instruction, wellbeing, lodging, exchange, and transportation. This approach covers arrangements in the open arena, offices, or certain establishments. Experimentally strategy can be deciphered all the more extensively. A few specialists give various meanings of strategy. That definition by and large can be ordered into two sorts, in particular the more underlined definition on the effect of activity on strategy, and the definitions that weigh on fundamental points and destinations as key arrangement models.

The main definition is what accentuates the effect of activities on strategies, as communicated by Richard Simeon "what governments really do and why ", Policy is the thing that the legislature does and for what reason it. Then, E Hugh Heclo was cited as saying by Oberlin Silalahi states that approach is a method of acting purposefully to tackle a few issues. While the second definition which underlines the points and destinations, among others, advanced by James $\mathrm{E}$ Anderson to be specific "a purposive strategy followed by an entertainer or set of entertainer in managing an issue or matter of concern "strategy is a course of activity which has a reason dictated by an entertainer or various entertainers in beating an issue or an issue. Friedrik in Wahab characterizes strategy as an activity that prompts an objective proposed by an individual, gathering, or government in a specific climate regarding the presence of specific impediments while searching for occasions to accomplish objectives or accomplish wanted objectives. 
Some of these definitions, more specifically policies can be defined as a set of decisions taken by a person or group in his quest to select and achieve certain goals in solving a problem. This understanding seems closer to the truth because decisions taken must have a specific agenda or purpose and is an effort to solve existing problems. Determination of policy is a decision from the leader of an institution to approve, change, or reject it. Decisions made The leadership really determines whether a policy is effective or not because In establishing a policy, it is necessary to identify problems and processes gathering problems, right down to establishing policies in response to problems that arise.

The policy making process is a political activity and a series the stages are interdependent and arranged according to a specific time sequence. 14 In the policy process offered many concepts by experts. Anderson in Djoko Widodo stated five steps in the policy process, namely the agenda setting, policy formulation, policy adoption, policy implementation, and policy assessment / evaluation. Reply as quoted by Djoko Widodo distinguishes the process culture in four stages, namely agenda setting, formulation and legimating of goal and program, program implementation, performance and impact, decision about the future of the policy and program. 16 And many more steps formulated by experts.

Making a decision from a policy should at least foundation on four principles, namely, the principle of efficiency, the principle of flexibility, the principle of the alternative barrier, and the principle of the laws decision making must follow-which schools will keep in the future. In general, the decisions taken by decision makers can.

can be divided into two, namely the programmed decision and nonprogrammed decisions. Programmed decisions are decisions that are structured or decisions that occur repeatedly. An organization usually has rules and procedures for how decisions are programmed. The decision maker only has to make the decision accordingly with existing guidelines. Meanwhile, decisions that are not programmed (non-decision programmed) is a decision that is unstructured or occurs rarely. Namely decisions that arise from extraordinary or unusual problems. Because it is not structured and rarely appears then decisions are not programmed and do not have detailed enough guidelines to handle every one the problem.

In dealing with a problem, a policy maker and decision makers will encounter an uncertainty. Certainty in policy making will be influenced by the information received. If the information received is accurate and reliable and the consequences the decision can be clearly predicted then the decision maker or policies will face certain conditions. Otherwise if the information is accepted inaccurate and cannot be trusted then a decision maker or the policy will experience uncertainty. Under such conditions this is precise and accurate information or data that is needed for solving problems in decision making.

\section{EMIS as a Basis for Policy Making in Mapenda Gunungkidul}

Mapenda (Madrasah and Religious Education) is one of the sections at the Ministry of Religion which has the authority and responsibility prepare, organize, implement, and evaluate education who are in madrasah and religious education in public schools. In running educational institutions, especially madrasas and education agama di sekolah umum tentu membutuhkan sebuah perencanaan yang matang sehingga pendidikan yang nantinya dilaksanakan akan berjalan dengan baik sesuai harapan, tujuan yang telah ditetapkan. Selain itu untuk menunjang terlaksananya sebuah perencanaan, dibutuhkan perangkat yang akan mendukung terlaksananya sebuah rencana yaitu sebuah kebijakan pendidikan. Kebijakan pendidikan adalah keseluruhan proses dan hasil perumusan langkah-langkah strategis pendidikan yang dijabarkan dari visi, misi pendidikan, dalam rangka mewujudkan tercapainya suatu tujuan pendidikan dalam suatu masyarakat untuk suatu kurun waktu tertentu. 
The Mapenda section as the implementing unit and the elaboration of the Ministry of Religion's policies at the district level is an institution that bridges the education units, namely madrasas and Islamic religious education teachers, and the Ministry of Religion of the Republic of Indonesia which is at the central level. As an extension of the Ministry of Religion in the field of madrasah education and religious education in public schools, the Mapenda section acts as the implementer of policies formulated by the center, although in certain technical matters Mapenda has the authority to determine policies. This is because structurally Mapenda's position is not burdened to formulate regulations as can be done by the education, youth and sports offices at the regional level, as stated by the Head of Mapenda:

Mapenda is obliged to do breakdown to policies of a technical nature so that the policy is easily understood by madrasas or school. Policies that come from the center or those that come from The Regional Office of the Ministry of Religion is basically a policy comprehensive. The policy appears based on information and suggestions from the District Office of the Ministry of Religion. In developing madrasah madrasah and education religion on school general in district Gunungkidul, Mapenda To do communication and dig information live from madrasa. Besides that communication too done with $\mathrm{K} 3 \mathrm{M}$, MGMP, or KKG so that it will appear clearly and real potential, strengths, weaknesses, and prospects are owned.

\section{Analysis of EMIS Implementation in Policy Making in Mapenda Ministry of Gunungkidul.}

Based on the research that has been done, policy making in the Mapenda environment it only deals with local policies religious education in the Gunungkidul Regency area. As an agency vertically under the Ministry of Religion, Mapenda has no authority full in making a policy. Mapenda's role as executor policies that have been made by the central Ministry of Religion, in this case the Director General Islamic education and policies issued by the Regional Office of the Ministry Religion of the Special Region of Yogyakarta.

Among the several policies in Mapenda, the ministry of religion Gunungkidul district, researchers took one of the policies, namely policy determination of teacher certification candidates. Policy targets for beneficiaries Teacher certification is an educator / teacher in madrasah and Islamic religious education teachers in schools. Determination of potential certification recipients for Islamic religious education teachers in schools carried out by Mapenda because Islamic religious education teacher coaching was carried out by Mapenda though structurally Islamic religious education teachers in public schools are below the Ministry of Education and Culture. In determining certification participants teachers who are under the guidance of mapenda need the following criteria fulfilled by potential certification recipients. These conditions include meeting 24 hours face to face, have met the requirements for a work period of 5 years and meet the age requirement. Determination of potential certification recipients can be done by viewing data and teaching history of teachers in EMIS. EMIS is a management information system that manages education data to complete both educators, students, educational staff, and facilities infrastructure. However, in the implementation, the existing data in EMIS are not yet available updated every day so that the movement of data is so fast sometimes cannot be recorded in the EMIS system. This is what led to Mapenda In determining policies in the Gunungkidul district, it is not strictly enforced based on EMIS data, but also based on physical reports from teachers and madrasah as well as suggestions from madrasah and KKG and MGMP.

Policy implementation requires readiness of both human resources and non-human resources. Candidate determination policy in its implementation, certification participants need existing resources at mapenda to implement the policy. Mapenda staff should understand the existing rules in determining teacher certification candidates in file validation can run optimally. 
Besides that, a mapenda as a policy maker must always monitor policy implementation and be ready to face all problems that arise in implementing the policy. For that we need cooperation with other organizations. The collaboration carried out is with professional organizations such as KKG, K3M and MGMP as well as with madrasas in Gunungkidul. The policy implementation process should have run more efficiently if the implementation of EMIS data collection goes well as well as always updated so that any data changes can be reported immediately and policy makers can use it as a basis for making Policy.

Making policies within the Mapenda of the Ministry of Religion Gunungkidul Regency is based on suggestions that have been submitted from the madrasa through a work meeting forum with Mapenda. However, for the future the EMIS system will always be improved and improved so that the data entered into the system EMIS validity can be recognized and can be used as supporting data policy maker. The current EMIS system is still vulnerable to multiple problems. Based on the researcher's search on the EMIS website that can be accessed at the address www.emispendis.kemenag.go.id the site is often not accessible or there is a statement "is experiencing problems". This of course will affect Mapenda's needs in accessing data. Data obtained is not up to date data or actual daily data from a Madrasah or Islamic religious education teachers, however, are data processed within a certain period. There is data that is the result of data collection in a certain period; it will certainly become obsolete data when used as a supporter of policy making. If the data results are used for mapping religious education on a national basis can of course be used as supporters of national or long-term policy making. Will but for data needs that must always be up to date as required by Mapenda in making policies such as giving policies assistance in the form of rehabilitation of places of worship as well as assistance with express boarding schools who need current data certainly cannot rely solely on EMIS data. Manual data retrieval is still necessary, such as through reports and proposals made by madrasah to be submitted to Mapenda. In addition, for sensitive policies such as determining candidates teacher certification participants as well as providing assistance in the form of party funds / finances Mapenda in policy making is more careful. Mapenda can't refer to existing data in EMIS but still requires data physically sent directly by educators and madrasa institutions need help.

Apart from the various shortcomings, management information systems education is needed to support decision making. The Ministry of Religion of Gunungkidul Regency is a vertical agency that must be ready at all times for the data required by the vertical agencies above it. The existence of an EMIS can help the ministry of religion in providing the need for such data and present it quickly when needed. The hope for the future is that there will be improvements and improvements to the data collection system EMIS and online data collection so expect the data to be generated from EMIS can always be up to date and is valid, reliable, timeline data and can always be accessed by users who need both in every decision making, research, and other needs that require data on madrasa and Islamic religious education teachers in public schools.

\section{Conclusion}

EMIS (Education Management Information System) is a method of formal management which is intended as a provider of educational information accurate and timely so that the decision-making process, planning, project development, and other educational management functions can be implemented effectively. The use of EMIS in Mapenda Gunungkidul is an effort to use technology that has been provided by the Ministry Religion. The existence of EMIS is felt to be very helpful in the retrieval process policies or speed up the performance of Mapenda when presenting and reporting Gunungkidul District education data .EMIS provides field data come from madrasas and Islamic religious education teachers Mapenda can use EMIS data as baseline and field data can be used as a basis for policy 
making in the Mapenda environment Gunungkidul district. Use of EMIS data in policy making in Mapenda's environment has reached $80 \%$.

The Education Management Information System as a base for taking policy in Mapenda of the Ministry of Religion of Gunungkidul Regency has not been fully usable, because the level of validity and updating (updating) the data is still imperfect. So that the EMIS data can only be used as supporting data and still require "manual" data through tracking and validation of physical data obtained from KKG, K3M, and MGMP. This is different from the online dapodik system developed by the Ministry of Education and Culture. Every policy making has started using the system management information. Therefore updating data, maximizing management, system improvement, and system administration capabilities must continue to be improved for the effectiveness and efficiency of EMIS as a basis for taking Policy.

\section{References}

[1].Departemen Agama RI. Tata Hubungan Kerja Direktorat Jenderal Kelembagaan Agama Islam, Jakarta: Departemen Agama, 2003

[2].Dokumen review kegiatan pendataan TP 2011/2012 diakses tanggal 26 Oktober 2012

[3].Dunn, William. Public Policy Analysis: An Introduction, terj Samudra Wibawa, dkk.

Yogyakarta: Gadjah Mada University Press, 1998

[4].Hanafi. M. Mamduh. Manajemen. Yogyakarta: UPP STIM YKPN, 2011

[5].KMA Nomor 2 tahun 2010 tentang Rencana Strategis Kementerian Agama tahun 2010-2014

[6].Kumorotomo, Wahyudi. dan Subando Agus Margono, Sistem Informasi Manajemen dalam Organisasi-organisasi Publik. Yogyakarta: Gadjah Mada University Press,2001

[7].Prawirosentono, Suyadi. Filosofi Baru Tentang Manajemen Mutu Terpadu Abad 21. Jakarta: Bumi Aksara, 2007.

[8].Rosyid, Daniel Muhammad. Optimalisasi Teknik Pengambilan Keputusan Secara Kuantitatif. Surabaya: ITS Press, 2009

[9].Siagian, Sondang P. Sistem Informasi Manajemen, Jakarta: Bumi Aksara, 2006

[10].Silalahi, Oberlin. Beberapa Aspek Kebijakan Negara, Yogyakarta: Liberty, 1989

[11].Syarip, Dodi Irawan, \& Rosidin. Sistem Manajemen Data dan Informasi Pendidikan

di Lingkungan Direktorat Jenderal Kelembagaan Agama Islam, Jakarta:Departemen Agama RI, 2003

[12].Tilaar. H.A.R. dan Riant Nugroho. Kebijakan Pendidikan; Pengantar untuk Memahami Kebijakan Pendidikan dan Kebijakan Pendidikan Sebagai Kebijakan Publik.Yogyakarta: Pustaka Pelajar, 2009 
[13].Wahab, Sholichin Abdul. Analisis Kebijakan; Dari Formulasi ke Implementasi Kebijakan Negara, Jakarta: Bumi Aksara, 1991

[14].Widodo, Djoko. Analisis Kebijakan Publik; Konsep dan Aplikasi Analisis Proses Kebijakan Publik. Malang: Bayumedia, 2007

[15].Winarno, Budi. Teori dan Proses Kebijakan Publik. Yogyakarta: Media Pressindo, 2002

[16].Febriyanto, E., Naufal, R. S., \& budiarty, frizca. (2019). Attitude Competency Assessment in the 2013 curriculum based on elementary school Prototyping methods. IAIC Transactions on Sustainable Digital Innovation (ITSDI), 1(1), 87-96. https://doi.org/10.34306/itsdi.v1i1.6

[15].Aini, Q., Sunarya, P. A., \& Bein, A. S. The Implementation Of Viewboard Of The Head Of Department As A Media For Student Information Is Worth Doing Final Research. IAIC Transactions on Sustainable Digital Innovation, 1(1), 18-25. 